ARTICLE

https://doi.org/10.1057/s41599-019-0315-9

\title{
Sustainability and bank risk
}

\author{
Bert Scholtens $^{1} \&$ Sophie van't Klooster (i) ${ }^{1}$
}

\begin{abstract}
Banks play a key role in society and are crucial for economic development. The existing literature finds a positive association between bank performance and sustainability, but tends to neglect the risk dimension. As human-driven processes interact with global social-ecological connectivity and exhibit cross-scale relationships, we investigate whether sustainability affects banks' individual default risk and their systemic risk, that is, their contribution to the risk of the financial system. As banks are financial intermediaries and there is no direct measure of their sustainability, we proxy for sustainability with banks' performance on environmental, social, and governance attributes, especially their policies and performance. We control for relevant bank, market and country characteristics. It shows that higher sustainability scores of banks significantly associate with lower default risk. We also establish that outperformance on sustainability reduces banks' contribution to systemic risk. Thus, it appears that banks' sustainability performance can spill over to the financial system. This implies sustainability is material for banks and their supervisors. Accounting for sustainability can augment bank risk management and prudential policy decision making, and provide guidance as to how to finance a transition towards an economic system that effectively internalizes externalities.
\end{abstract}

\footnotetext{
${ }^{1}$ University of Groningen - Faculty of Economics and Business, Nettelbosje 2, 9747 AE Groningen, The Netherlands. Correspondence and requests for materials should be addressed to B.S. (email: I.j.r.scholtens@rug.nl)
} 


\section{Introduction}

anks play a central and crucial role in society and they mediate capital and assets between surplus and deficit spending households throughout the economy (Cull et al., 2013). As such, they bear great responsibility for sustainable development (Scholtens, 2017; Galaz et al., 2018). Mark Carney, governor of the Bank of England, points out that especially climate change is a huge concern for the financial industry (Carney, 2015). However, so far, bank management and banking supervisors do not explicitly account for sustainability and responsibility of banks. We want to find out if this omission is material from a risk perspective. In this respect, we account not only for banks' default risk, but for the risk of the financial system as well. It is important from an academic and societal point of view to examine the relationship between sustainability and (systemic) bank risk because the potential consequences of cross-scale systemic environmental risks with global effects are increasing (Homer-Dixon et al., 2015; Keys et al., 2019). In particular, it becomes increasingly clear that human-driven processes interact with global social-ecological connectivity and exhibit cross-scale relationships (Galaz et al., 2018). Then, it is relevant to study how this works out in the case of banking, which plays such a crucial role in society (Berger et al., 2017).

Most research focuses on how sustainability relates to the costs and revenues of firms (Schröder, 2014; Friede et al., 2015). The main finding from this literature is that there is a small but positive association between the two. It also shows that most of the literature does not distinct between industries. However, different industries relate in quite different ways to sustainability due to variation in their production structure and in their position in the economic value chain (Heal, 2008; Dafermos et al., 2018). Further, sustainability is hard to measure at the firm or industry level (Chatterji et al., 2009; Semenova and Hassel, 2015; Capelle-Blancard et al., 2019). Some scholars argue the financial sector should play a crucial role in the transformation of the current economic system to a more sustainable one (Kemp-Benedict, 2018). This implies accounting for sustainability in order to reduce the external (unpriced) economic effects of production (Heal, 2008).

Given the mounting evidence of the importance of sustainability on firm performance (Margolis et al., 2009; Friede et al., 2015; Ferrell et al., 2016), it is highly surprising that there is little knowledge about how it influences banks' default risk: the risk of a bank being unable to fulfill its obligations of repaying its debt. This is important as default risk not only affects the bank itself, but also may influence the entire financial system. There are few studies that explicitly consider default risk of banks in relation to sustainability. These studies suggest that there appears to be a neutral or negative relationship between the two (BoutinDufresne and Savaria, 2004; Bouslah et al., 2018). However, because of the importance of human-environment interactions (Keys et al., 2019), we also want to account for the so-called systemic risk of the banking industry. In this respect, systemic risk is the risk resulting from bank operations for the financial system as a whole (Beale et al. 2011; Acharya et al., 2012; Laeven et al., 2016; Berger et al., 2017). Homer-Dixon et al. (2015) argue that crises will increasingly arise from the conjunction of three underlying, long-term, and causally linked global trends. These are the sheer scale of human activity in relation to Earth's resources, the rise in interconnectivity, and the increasing homogeneity, or declining diversity, of human cultures, institutions, practices, and technologies (Homer-Dixon et al., 2015). Therefore, we investigate if and how sustainability relates to banks' default risk and their systemic risk.

We show that banks with high sustainability scores (i.e., those who perform relatively well) have lower default risk, as well as lower contribution to financial system risk. Especially the social dimension of sustainability appears to be important. This may be due to the nature of bank services, which to a great extent rely on information production and processing, as well as social networks. The findings suggest that both banks and financial authorities should extend the scope of their risk analysis and management and explicitly account for information about how banks interact with sustainability.

\section{Banks and sustainability}

The global financial crisis of 2007-2009 led to calls for responsible conduct of the finance industry (Cornett et al., 2016). Politically motivated groups and non-governmental organizations insist financial institutions take responsibility for social ills such as human rights violations and climate change by virtue of the economic operations and activities they finance. For example, Amnesty International (2016) requires banks commit to stop all financial activities related to illegal arms or arms destined to an illegal use. Carbon Tracker Initiative (2017) urges pension funds to divest from fossil fuel companies in order to facilitate the transformation towards a carbon-neutral economic system. Increasingly, the financial sector tries to account for such calls. Several initiatives have been set up to stimulate this debate and to try to achieve financial firms integrate responsibility in their business model. For example, the Equator Principles address how banks can account for social and environmental issues in project finance, and the Principles for Responsible Investment stimulate investors to use responsible investment to enhance returns and improve risk management.

A responsible business community can mitigate the impact of poor institutions and reduce corruption (Dixit, 2015). Further, the interaction between global financial markets and the economy influences sustainable development (Huang, 2011). For individual organizations, sustainability translates into corporate social responsibility (Dahlsrud, 2008). Usually, economists measure corporate sustainability via the performance of firms regarding their environmental and social impact and policy, as well as their governance (Chatterji et al., 2009; Ferrell et al., 2016). For financial institutions, this is problematic as they mediate within the economy; their financial products enable other agents to produce their goods and services. The assets of banks are predominantly financial assets, in contrast to those of non-financial companies (Tobin, 1987). Banks provide financial services such as lending, underwriting, guarantees, and investment to all kinds of agents, which requires producing and processing information and depends on network connections (Greenbaum and Thakor, 2007). As such, the banks do not have a direct effect on environmental and social characteristics, but only an indirect one via their lending, investment and financing decisions. In screening potential borrowers, they come across the operations and prospects of the counterparty and can influence decisions about design of the projects they are to finance. Therefore, information about their policies is crucial (Greenbaum and Thakor, 2007).

The economic system directly affects sustainability (e.g., pollution, inequality) and uses resources (e.g., water, human capital, energy). Hence, sustainable development is driven by the organization and efficiency of the economic system. The state of and expectations regarding sustainable development inform banks' sustainability policies. At the corporate level, sustainability usually is proxied by environmental, social and governance characteristics (Semenova and Hassel, 2015; Dorfleitner et al., 2015; Friede et al., 2015). As intermediaries, banks cannot directly influence sustainable development. However, in their financial services, they can account for environmental, social, and governance characteristics and policies of firms and organizations in 
their financing policy and decision. Further, at the aggregate and macro-level, they interact with the economic system via their balance sheets and their financial market operations. To manage their risks and to organize funding, they cooperate with other financial institutions. Financial authorities monitor and regulate both individual banks and markets and the financial system as a whole (Greenbaum and Thakor, 2007).

Several country studies investigate sustainability in the financial industry (e.g., Simpson and Kohers, 2002 (US); Scholtens, 2007 (the Netherlands); Menassa, 2010 (Lebanon); CalladoMunoz and Utrero-Gonzalez, 2011 (Spain); Uddin et al. (2012) (Bangladesh); Saxena and Kohli, 2012 (India); Bolton, 2013 (US); Kamal, 2013 (Egypt); Adewale and Rahmon, 2014 (Nigeria); Malik and Nadeem, 2014 (Pakistan); Paulik et al., 2015 (Czech Republic); Cornett et al., 2016 (US); Lins et al., 2017 (US)). This literature shows wide variation in how it deals with sustainability: from actual resource usage to generic ratings, and from topical aspects to broad categories or even catch-all indicators. The predominant conclusion is that sustainability results in financial outperformance (the studies of Scholtens (2007), Paulik et al. (2015), and Gonenc and Scholtens (2019) being an exception). Cornett et al. (2016) examine banks' sustainability in the US in the context of the global financial crisis and establish they get rewarded for socially responsible behavior.

In addition, there are several studies using an international sample (for example, Chih et al., 2010; Soana, 2011; Wu and Shen, 2013; Ciciretti et al., 2014; $\mathrm{Hu}$ and Scholtens, 2014; Mallin et al., 2014; Jo et al., 2015; Aginer et al., 2016; Shen et al., 2016; $\mathrm{Wu}$ et al., 2017). The results from multi-country studies generally point in the same direction as those on individual countries. Chih et al. (2010) provide an overview of the literature and conclude that many key characteristics of social performance are to be positively associated with financial ratios and performance indicators in the banking industry (see also Ioannou and Serafeim, 2015). Wu and Shen (2013) argue that the more banks engage with sustainability, the better their financial performance as reflected in several bank efficiency and performance ratios. They confirm these findings in later research (Shen et al., 2016; Wu et al., 2017). Ciciretti et al. (2014) suggest banks with higher sustainability scores have lower cost of debt and equity. Mallin et al., (2014) and Platonova et al. (2016) establish that Islamic banking too shows the positive effects of responsible conduct. Jo et al. (2015) argue banks' environmental performance improves their operational efficiency and as such results in better financial performance. Very diverse sustainability and financial performance variables are used in these studies. Further, there is substantial variation in the use of estimation methods. This criticism is reminiscent of the critical reflection regarding the study of CSR by Orlitzky et al. (2003), Margolis et al. (2009), and Dam and Scholtens (2015). Only few studies explicitly address causality. Those who do so show that it predominantly is sustainability that precedes risk (Scholtens, 2008; Cornett et al., 2016; Bouslah et al., 2018; Capelle-Blancard et al., 2019; Gonenc and Scholtens, 2019).

We aim to contribute to the literature about the interaction between banks and sustainability by investigating how sustainability relates to individual bank risk (default risk) and how it affects financial system risk (systemic risk).

\section{Model}

To investigate the relationships between bank risk and sustainability, we rely on generic indirect measures of sustainability and look into the influence of its constituting dimensions (i.e., environmental, social and governance factors). For bank risk, in line with the literature (Boutin-Dufresne and Savaria, 2004; Greenbaum and Thakor, 2007; Basel Committee on Banking
Supervision, 2015; Cornett et al., 2016; Bouslah et al., 2018), we use different measures, namely their $Z$-Score (Berger et al., 2017) and the standard deviation of the return on equity (Laeven and Levine, 2009). We compute the $Z$-score as the sum of the return on average assets (ROAA) and the capital-asset-ratio (CAR) divided by the standard deviation of the return on assets over a pre-specified period. It represents the number of standard deviations by which returns have to decline in order to deplete a bank's equity capital. The variation in the return on equity relates the net income of a bank to its equity (Laeven and Levine, 2009; Berger et al., 2017).

We assess the systemic risk contribution by SRISK. SRISK is the expected capital shortfall of a bank during a period of distress in which the financial market declines substantially, and shows the amount of capital that a bank is expected to need in case of a financial crisis (Brownlees and Engle, 2016). SRISK measures the capital shortfall of a bank conditional on a severe market decline, and is a function of its size, leverage and risk. This metric can deal with drawbacks from more conventional measures that are used in this arena (see Dietz et al., 2016; Battiston et al., 2017). In constructing the SRISK measure, we do not limit SRISK to a threshold of zero (as in Acharya et al., 2012), but allow for negative values too. This is because highly capitalized banks with a large capital buffer can absorb systemic shocks that will reduce the overall systemic risk in the system (Laeven et al., 2016). Appendix 4 explains how SRISK is calculated.

Most of the literature about financial and social performance finds that it is financial outperformance that drives social outperformance (Margolis et al., 2009; Chih et al., 2010; Schröder, 2014; Dorfleitner et al., 2015; Friede et al., 2015). In contrast, as discussed above, the few studies that specifically focus on the relationship between firms' risk and social, environmental and governance performance detect that it usually is changes in the latter that precede (changes) in risk (Scholtens, 2008; Sun and Cui, 2014; Cornett et al., 2016; Bouslah et al., 2018). Therefore, we opt for the risk measures as the dependent variable to be explained by sustainability variables, next to others. However, we will also show model estimations with social performance being explained with the help of risk.

We include a large number of controls. First, we include bankspecific variables such as size of assets held, capital buffer, funding, non-interest income, and deposits. Second, we have financial market size to control for the financial system. In addition, GDP growth, public debt, and inflation control for the economy. Time fixed effect account for bank regulation and supervision. The controls are motivated by the way in which banks operate (see Beale et al., 2011; López-Espinosa et al., 2013; Hull, 2018), and are in line with other studies that investigate social and financial performance (Laeven and Levine, 2009; Chih et al., 2010; Friede et al., 2015; Cornett et al., 2016; Lins et al., 2017; Bouslah et al., 2018; Capelle-Blancard et al., 2019). We do not include additional institutional features as suggested by Waddock and Graves (1997) because our sample banks operate on the basis of the same type of institutions and regulations in the Euro area of the European Union. They all are subject to identical monetary and prudential supervision, operate on liberalized banking markets, and face the same regulation regarding payment systems, financial services and capital mobility.

Thus, first, we investigate the relationship between banks' sustainability and individual bank default risk, in which the following setup is applied:

$$
\begin{aligned}
\text { Default risk }_{i, t}= & \alpha+\beta_{1} \text { Sustainability }_{i, t-1}+\beta_{2} \text { Controls }_{i, t-1} \\
& +\beta_{3} \text { Controls }_{c, t-1}+\omega_{t}+\gamma_{i}+\varepsilon_{i, t},
\end{aligned}
$$


where the measure for individual bank default risk refers to bank $i$ at time $t$, Sustainability to the prior year's sustainability rating of bank $i$, controls include bank-specific characteristics of bank $i$ at time $t-1$, such as tier-1 capital ratio, deposit ratio, non-interest income, and short-term funding, and country-specific characteristics of country $c$ at time $t-1$, such as GDP growth, public debt ratio, inflation, and stock market capitalization. $\omega_{t}$ are time fixed effects, $\gamma_{i}$ bank fixed effects and $\varepsilon_{i, t}$ represents the error term. In a sensitivity analysis, we swap Sustainability and Default Risk to find out whether specification (1) is valid indeed.

The second regression model accounts for the relationship between sustainability and a bank's contribution to systemic risk:

$$
\begin{aligned}
& \text { Systemic risk contribution }_{i, t}=\alpha+\beta_{1} \text { Sustainability }_{i, t-1} \\
& +\beta_{2} \text { Controls }_{i, t-1}+\beta_{3} \text { Controls }_{c, t-1}+\omega_{t}+\gamma_{i}+\varepsilon_{i, t},
\end{aligned}
$$

here, the dependent variable is systemic risk for bank $i$ at time $t$. The bank $i$ and country $c$ controls are the same as those in Eq. (1): bank-specific controls are tier-1 capital ratio, deposit ratio, noninterest income, and short-term funding, country-specific controls are GDP growth, public debt ratio, inflation, and stock market capitalization. As bank assets appear to be non-stationary after running a Fisher unit root test, we transform it into stationary variables to make sure the model is correctly specified. As with model (1), we will also swap sustainability and systemic risk for sensitivity purposes.

We estimate models (1) and (2) using a fixed effects regressions, based on the results of the Hausman test. We cluster standard errors at the bank level to correct for heteroskedasticity and autocorrelation. Time-fixed effects are included to account for time trends and those of the Global Financial Crisis. In addition, the explanatory variables are lagged by one year to help control for potential endogeneity. This lag can be motivated by theoretical and practical reasons. The former relates to the argument of Garcia-Castro et al. (2010) that lagging by one year controls for previous year's performance effects on subsequent performance or changes in strategy. Further, there is no theoretical reason as to why longer lags would have an impact. The practical reason relates to the limited time-span of the data series. Using longer lag-lengths would considerably reduce the number of observations.

\section{Data}

Our sample (See Appendix 1) relates to banks situated in Euro countries starting January 2002 until 2016. They are subject to the same regime of monetary and prudential supervision (as such, we do not face the problem of differences in relevant institutions affecting the results, see Waddock and Graves, 1997). As to sustainability, it is unfortunate that there are only very few independently audited and verified sustainability reports. Several commercial rating agencies produce assessments of firms' corporate social responsibility. They do so by assessing firms regarding policies and some resource use and emissions data. The academic literature acknowledges the drawbacks of using these data (Garcia-Castro et al., 2010; Semenova and Hassel, 2015; Dorfleitner et al., 2015). In particular, ratings do not inform about sustainability as such and tend to focus on policies instead of performance. However, as of yet, there is no alternative. Therefore, we rely on Thomson Reuters DataStream to obtain information about corporate social responsibility from their ASSET4 database. This used in several other academic studies too (Dorfleitner et al., 2015; Friede et al., 2015). We opted for this database as it is part of our university's subscription to a much more encompassing database. As the sustainability score is the main variable of interest, we exclude banks without such ratings. The overall rating comprises an environmental, social and corporate governance pillar and is an equally weighted score (see Appendix 3). The ASSET4 database holds publicly available information about 226 indicators to create an integrated view of corporate performance. The environmental pillar consists of the categories emission reduction, product innovation and resource reduction. The social pillar consists of the categories community, diversity, employment quality, health and safety, human rights, product responsibility, and training and development. The corporate governance pillar contains the following categories: board functions, board structure, compensation policy, shareholder rights, and vision and strategy. The sustainability score we use is an aggregate equally weighted measure of the three pillars. After matching Thomson Reuters ASSET4 ratings with the banks, our final sample includes 43 banks from 10 countries. This includes all banks in the Euro area that qualify as system banks, i.e., banks that are most relevant for the global financial system. As such, we study the most important banks.

Financial data are from Datastream and World Bank World Development Indicators, as are the bank-specific and countryspecific control variables. The data are subject to relevant limitations. First, as mentioned, sustainability ratings data are not independently verified and audited. Further, most data is only available on a yearly basis. Therefore, we can calculate the measures for bank default risk only for a small sample, which affects the estimation of our systemic risk measure. As a financial breakdown occurs suddenly, yearly data cannot accurately assess the effect on a bank its systemic risk contribution. We look forward to be able to both more accurate and granular data to improve the analysis. Appendix 2 gives an overview of the definition of the variables used and provides their source.

Table 1 displays the descriptive statistics. The SRISK measure show that this is the only variable displayed in Euros. As this makes interpretation of its coefficient complicated, the percentage change of SRISK will be used in regressions. Comparing the $Z$ Scores to the US bank sample of Berger et al. (2017), our mean value is 57.456 , whereas they have calculated a value of 36.053 , suggesting that the European banks are more stable. The Sustainability score ranges from 13.45 to 288.14 , with a mean of 186.412 .

Bank risk and sustainability. We estimate the effect of sustainability on bank default risk with different risk measures to test our first hypothesis, which holds that sustainability affects bank default risk. Table 2 presents the results. It shows a significant association between the sustainability score and bank default risk. The estimation results for our first risk metric ( $Z$-Score) reveal that a bank's sustainability significantly associates with lower default risk: An increase of the sustainability score by one unit is associated with an increase of the bank's $Z$-Score by 0.303 units. The sustainability score negatively relates to the standard deviation of the return on equity, being our second risk measure, but this is only marginally significant. This suggests that an increase in the sustainability score by one unit is to be associated with a decrease of the standard deviation of the return on equity by 0.001 , implying a decrease in bank default risk. We conclude that in banking, sustainability negatively relates to default risk. This finding is consistent with previous studies (Oikonomou et al., 2012; Sun and Cui, 2014; Capelle-Blancard et al., 2019).

Next, we associate bank sustainability with systemic risk. Table 3 presents the estimation results of our model as to how banks' sustainability scores relate to their systemic risk contribution. We observe that higher sustainability scores coincides with significantly lower systemic risk contributions. More specifically, an increase of a bank's sustainability score by one unit associates with a reduction of its systemic risk contribution by 1.522 
Table 1 Descriptive statistics

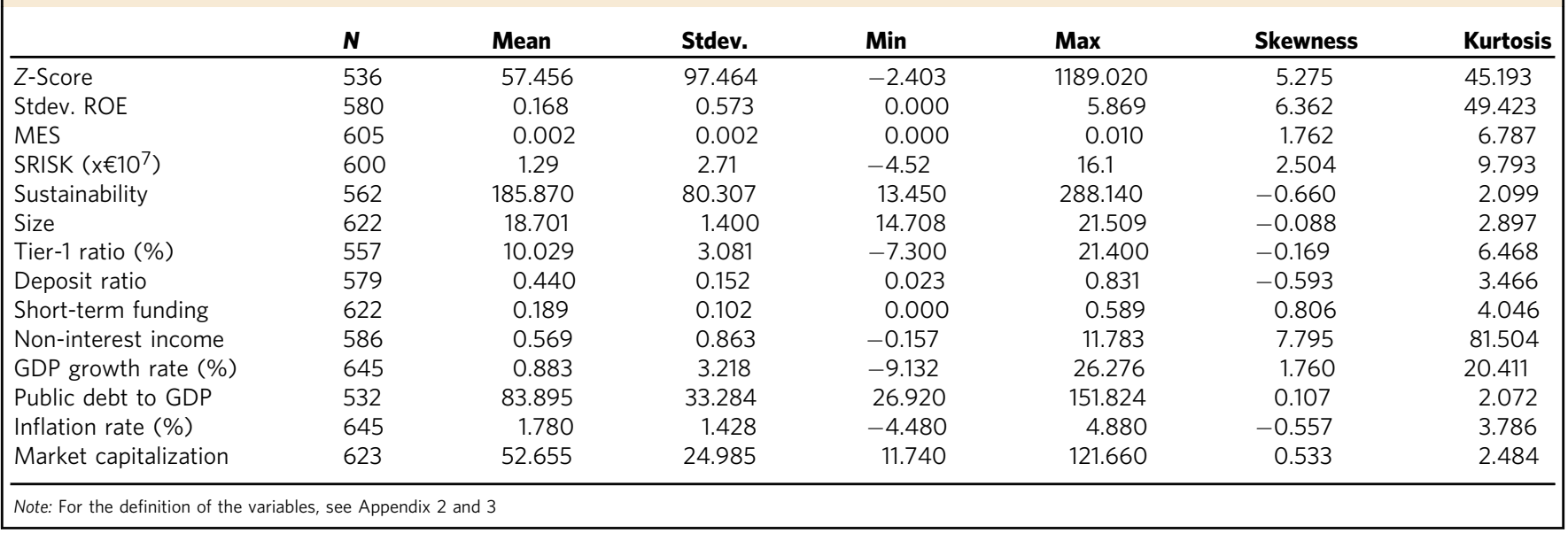

Table 2 Bank default risk and sustainability

\begin{tabular}{lccc} 
& $\begin{array}{l}\text { Z-Score } \\
\text { Full model }\end{array}$ & $\begin{array}{l}\text { Z-Score } \\
\text { Full model robust-cluster }\end{array}$ & $\begin{array}{l}\text { Stdev. ROE } \\
\text { Full model robust-cluster }\end{array}$ \\
\hline Sustainability & $0.303^{\star \star}(0.142)$ & $0.303^{\star}(0.154)$ & $-0.001^{\star}(0.001)$ \\
Size & $14.813(25.663)$ & $14.813(23.502)$ & $-0.186^{\star}(0.106)$ \\
Tier-1 capital ratio & $2.511(2.810)$ & $2.511(2.893)$ & $-0.024^{\star \star}(0.011)$ \\
Deposit ratio & $-87.834(81.290)$ & $-87.834(115.657)$ & $-1.227^{\star \star \star}(0.420)$ \\
Non-interest income & $7.138(17.153)$ & $7.138(18.798)$ & $-0.113^{\star *}(0.051)$ \\
Short-term funding & $-167.629^{\star \star}(77.524)$ & $-167.629^{\star}(89.988)$ & $-0.465(0.280)$ \\
GDP growth rate & $1.595(1.920)$ & $1.595(1.269)$ & $-0.013(0.010)$ \\
Public debt to GDP & $-0.075(0.447)$ & $-0.075(0.480)$ & $0.000(0.001)$ \\
Inflation rate & $2.264(6.817)$ & $2.264(7.910)$ & $-0.022(0.063)$ \\
Market capitalization & $-0.308(0.581)$ & $-0.308(0.551)$ & $-0.006(0.004)$ \\
Time fixed effects & Yes & Yes & Yes \\
Bank fixed effects & Yes & Yes & Yes \\
Adjusted R-squared & 0.138 & 0.138 & 0.174
\end{tabular}

Note: For the exact definition of the variables, see Appendix 2. Appendix 1 reports the sample banks. All explanatory variables are lagged by one year. Robust standard errors are reported in the parentheses

${ }^{*}$ indicates significance at the ten percent level

**indicates significance at the five percent level and

$\star \star \star$ indicates significance at the one percent level

\section{Table 3 Systemic risk contribution and sustainability}

\begin{tabular}{|c|c|c|c|}
\hline & $\begin{array}{l}\text { SRISK \% } \\
\text { Full model }\end{array}$ & $\begin{array}{l}\text { SRISK\% } \\
\text { Full model robust-cluster }\end{array}$ & $\begin{array}{l}\text { SRISK\% } \\
\text { Full model robust-cluster }\end{array}$ \\
\hline $\begin{array}{l}\text { Sustainability } \\
\text { Risk (Z-Score) }\end{array}$ & $-1.552^{\star}(0.921)$ & $-1.552^{\star}(0.855)$ & $\begin{array}{r}-1.457^{\star \star}(0.655) \\
-0.269(0.234)\end{array}$ \\
\hline Size & 38.433 (163.509) & $38.433(140.065)$ & $75.023(85.580)$ \\
\hline Tier-1 capital ratio & $-7.044(18.924)$ & $-7.044(16.219)$ & $-3.645(15.287)$ \\
\hline Deposit ratio & $-286.236(522.864)$ & $-286.236(471.565)$ & $-255.494(477.694)$ \\
\hline Non-interest income & $-42.932(110.353)$ & $-42.932(52.857)$ & $-37.768(60.078)$ \\
\hline Short-term funding & $125.656(510.723)$ & $125.656(406.504)$ & $-65.981(389.476)$ \\
\hline GDP growth rate & $-17.966(12.601)$ & $-17.966(16.671)$ & $-20.890(17.318)$ \\
\hline Public debt to GDP & $1.483(2.955)$ & $1.483(2.657)$ & $0.847(2.428)$ \\
\hline Inflation rate & $103.288^{\star \star}(44.182)$ & $103.288^{\star \star}(47.074)$ & $98.524^{\star \star}(44.453)$ \\
\hline Market capitalization & $-12.367^{\star \star \star}(3.667)$ & $-12.367^{\star}(6.603)$ & -10.101 (6.159) \\
\hline Time fixed effects & Yes & Yes & Yes \\
\hline Bank fixed effects & Yes & Yes & Yes \\
\hline Adjusted $R$-Squared & 0.092 & 0.092 & 0.087 \\
\hline
\end{tabular}


Table 4 Individual responsibility pillars, bank risk and systemic risk

\begin{tabular}{|c|c|c|c|c|c|c|}
\hline & $\begin{array}{l}\text { Z-Score } \\
\text { Full Model Robust- } \\
\text { cluster }\end{array}$ & $\begin{array}{l}\text { Z-Score } \\
\text { Full model robust-cluster }\end{array}$ & $\begin{array}{l}\text { Z-Score } \\
\text { Full model robust- } \\
\text { cluster }\end{array}$ & $\begin{array}{l}\text { SRISK\% } \\
\text { Full model robust- } \\
\text { cluster }\end{array}$ & $\begin{array}{l}\text { SRISK\% } \\
\text { Full model robust- } \\
\text { cluster }\end{array}$ & $\begin{array}{l}\text { SRISK\% } \\
\text { Full model robust- } \\
\text { cluster }\end{array}$ \\
\hline $\begin{array}{l}\text { Sustainability: } \\
\text { environmental }\end{array}$ & $0.312(0.216)$ & & & $-3.698^{\star}(1.896)$ & & \\
\hline Sustainability: social & & $0.769^{\star \star}(0.355)$ & & & $-3.596^{\star \star}(1.665)$ & \\
\hline $\begin{array}{l}\text { Sustainability: } \\
\text { governance }\end{array}$ & & & $0.546(0.357)$ & & & $-0.267(1.924)$ \\
\hline Risk (Z-Score) & & & & $-0.305(0.239)$ & $-0.261(0.227)$ & $-0.323(0.247)$ \\
\hline Size & 25.065 (21.495) & $15.839(22.638)$ & $26.088(21.363)$ & $70.168(92.240)$ & $73.578(91.026)$ & $-11.142(85.975)$ \\
\hline Tier-1 capital ratio & $2.031(2.828)$ & $2.810(2.850)$ & $2.523(2.866)$ & $-1.169(14.890)$ & $-4.473(15.758)$ & $-0.000(14.510)$ \\
\hline Deposit ratio & $-82.423(115.668)$ & $-74.277(109.304)$ & $-80.442(114.987)$ & $-216.306(465.978)$ & $-324.897(493.975)$ & $-323.016(498.439)$ \\
\hline Non-interest income & $5.721(19.944)$ & $8.643(19.279)$ & $6.264(18.468)$ & $-30.324(58.044)$ & $-47.153(62.179)$ & $-32.089(60.679)$ \\
\hline Short-term funding & $-141.921(84.656)$ & $-165.732^{\star}(86.587)$ & $-168.550 *(91.878)$ & $-160.728(398.742)$ & -110.304 (399.369) & $-159.327(439.804)$ \\
\hline GDP growth rate & $1.846(1.253)$ & $1.399(1.272)$ & $1.770(1.251)$ & $-21.834(16.112)$ & $-20.242(17.903)$ & $-22.021(17.808)$ \\
\hline Public debt to GDP & $-0.137(0.511)$ & $0.022(0.467)$ & $-0.092(0.491)$ & $1.301(2.496)$ & $0.358(2.394)$ & $0.983(2.426)$ \\
\hline Inflation rate & $3.772(7.709)$ & $1.923(7.828)$ & $2.993(7.909)$ & $92.936^{\star \star}(42.646)$ & $100.591^{\star \star}(45.315)$ & $90.543^{\star \star}(42.682)$ \\
\hline Market capitalization & $-0.313(0.569)$ & $-0.278(0.545)$ & $-0.379(0.541)$ & $-10.334^{\star}(6.098)$ & $-10.206(6.095)$ & $-10.125(6.124)$ \\
\hline Time fixed effects & Yes & Yes & Yes & Yes & Yes & Yes \\
\hline Bank fixed effects & Yes & Yes & Yes & Yes & Yes & Yes \\
\hline Adjusted $R$-Squared & 0.120 & 0.140 & 0.133 & 0.089 & 0.087 & 0.081 \\
\hline
\end{tabular}

percentage points. As such, this suggests that banks' sustainability is inversely related with their systemic risk contribution.

To account for the sensitivity of the results, we engage in additional checks. First, we run each model with the three individual sustainability pillars (environmental, social, governance) separately on our main dependent variables for the first and second hypothesis. It shows in Table 4 that the main dimension regarding the significant relationship of the $Z$-Score and sustainability in the banking industry is the social pillar as it is significant at a $5 \%$ level, whereas the other two pillars are not significant. This makes sense because the direct environmental footprint of financial institutions is limited and bank governance is highly institutionalized (Basel Committee on Banking Supervision, 2015). The social dimension might be impactful as it closely relates to the type of business the banks engage in, which is highly reliant on human and social capital. This finding is in line with that of Lins et al. (2017) for non-financial business.

Further, relating to ordering effects, we again estimate model (1) but now the dependent variable and the main variable of interest are swapped. That is, we estimate if sustainability is explained by (one year lagged) risk. The results are in Appendix 5. It shows that both risk measures do not significantly associate with the sustainability measure. This is in line with previous studies regarding the relationship between sustainability and financial risk (Scholtens, 2008; Sun and Cui, 2014). Further, we re-estimate model (2) with sustainability as the dependent and systemic risk as the explanatory variable. This is reported in Appendix 6. It shows that SRISK has a no significant association with Sustainability.

The regression results for the systemic risk measure also show significance in the case of the social pillar; the environmental pillar is only marginally significant. Banking to a large extent is pure people business and depends on access to networks (Greenbaum and Thakor, 2007). Then, having a committed and motivated workforce can make a substantial difference in keeping customers and in attracting new ones. Again, the governance score does not have a significant influence on bank default risk or systemic risk contribution. This may relate to the fact that there is very little leeway for banks in this respect, due to extensive regulation by monetary and financial authorities.

We also investigated if outliers influence the results and potentially give biased results. To deal with the possibility of a bias in our results, we remove extreme values of the sustainability score by taking out the top and bottom $1 \%$ of the scores. It appears the results remain robust to removing outliers.

Potential for sustainability in mitigating bank risk. Increasingly, human-driven processes interact with global socialecological connectivity and exhibit cross-scale relationships. In this respect, we study whether banks' sustainability interacts with their default risk and their systemic risk. Banks are intermediaries and it is not clear how their operations affect sustainability. Therefore, we rely on information about banks' performance regarding environmental, social and governance characteristics, i.e., their sustainability score, which reflects in their lending operations. We study 43 banks headquartered in the Euro area for the period 2002-2016.

We establish that sustainability negatively associates with bank risk: Banks with high sustainability scores have significantly less default risk. This holds for different proxies of default risk. We also show that a high sustainability score goes hand in hand with a lower systemic risk contribution. We conclude that sustainability coincides with lower bank risk and that it associates with less systemic risk. Several robustness tests confirm these results. Interestingly, separating the sustainability score into the three individual pillars shows that the social pillar is the main driver of the decrease in bank default risk and its systemic risk contribution. This is in line with the intuition that banking is a service industry; highly relying on human capital. Its direct environmental footprint is limited and it faces severe regulation and supervision regarding the corporate board, which reduces the scope to vary governance.

These novel findings complement the extant debate about the relationship between financial performance and sustainability in the international banking industry (Boutin-Dufresne and Savaria, 2004; Bouslah et al., 2018). The results on bank default risk align with the findings of the positive effects of responsibility of nonfinancial firms (Luo and Bhattacharya, 2009; Sun and Cui, 2014), whereas our results regarding systemic risk contribution provide a novel insight regarding the impact of sustainability on banking.

The findings of this paper have important implications. First, the result that better sustainability is to be associated with lower default risk and systemic risk contribution enhances our understanding of what makes up bank risk. Further research should 
examine how banks can improve sustainability to mitigate risk. This could help banks strengthen risk management, which is of great importance to society. Second, the positive role of banks' social responsibility in relation to their systemic risk contribution suggests financial authorities should integrate sustainability into their supervisory mechanisms. Further research to determine as to how exactly sustainability drives risks in the financial system will help central banks and other supervisory authorities in their quest to lower systemic risk and to mitigate the effect of future banking crises. Lastly, our study shows that policies regarding the promotion of sustainability need to account for industry specifics.

\section{Data availability}

The datasets generated during and/or analyzed during the current study are not publicly available due to the fact that they were sourced from proprietary databases of Thomson Reuters DataStream to which the university, where the authors are affiliated, subscribes. The data are available from the corresponding author on reasonable request when the proprietor can agree.

Received: 9 April 2019 Accepted: 20 August 2019

Published online: 10 September 2019

\section{References}

Acharya V, Engle R, Richardson M (2012) Capital shortfall: a new approach to ranking and regulating systemic risks. Am Econ Rev 102:59-64

Adewale MT, Rahmon TA (2014) Does corporate social responsibility improve an organization's financial performance? Evidence from Nigerian banking sector. J Corp Gov 13(4):52-60

Aginer D, Demirguc-Kunt A, Huizinga H, Ma K (2016) Corporate governance and bank capitalization strategies. J Financ Inter 26:1-27

Amnesty International (2016) Banks, arms and human rights violations. Amnesty International, Luxembourg

Basel Committee on Banking Supervision (2015) Corporate governance principles for banks. Bank for International Settlements, Basele

Battiston S, Manel A, Monasterolo I, Schütze F, Visentin G (2017) A climate stress test of the financial system. Nat Clim Change 7:283-290

Beale N, Rand DG, Battey H, Croxson K, May RM, Nowak MA (2011) Individual versus systemic risk and the regulator's dilemma. Proc Natl Acad Sci 108:12647-12652

Berger AN, El Ghoul S, Guedhami O, Roman RA (2017) Internationalization and bank risk. Manag Sci 63:2283-2301

Bolton B (2013) Corporate social responsibility and bank performance. Working paper. https://papers.ssrn.com/sol3/papers.cfm?abstract_id=2277912

Bouslah K, Kryzanowski L, M'Zali B (2018) Social performance and firm risk: impact of the financial crisis. J Bus Ethics 149:643-669

Boutin-Dufresne F, Savaria P (2004) Corporate social responsibility and financial risk. J Invest 13:57-66

Brownlees C, Engle RF (2016) SRISK: a conditional capital shortfall measure of systemic risk. Rev Financ Stud 30:48-79

Callado-Munoz FJ, Utrero-Gonzalez N (2011) Does it pay to be socially responsible? Evidence from Spain's retail banking sector. Eur Financ Manag 17:755-787

Capelle-Blancard G, Crifo P, Diaye M, Oueghlissi R, Scholtens B (2019) Sovereign bond yield spreads and sustainability: an empirical analysis of OECD countries. J Bank Financ 98:156-169

Carbon Tracker Initiative (2017) 2 Degrees of Separation. Transition Risk for Oil and Gas in a Low Carbon World. Carbon Tracker Initiative, London

Carney M (2015) Breaking the Tragedy of the Horizon-climate change and financial stability. Speech given at Lloyd's of London, 29 September 2015. http://www.fsb.org/wp-content/uploads/Breaking-the-Tragedy-of-theHorizon-\%E2\%80\%93-climate-change-and-financial-stability.pdf. Accessed 5 Oct 2018

Chatterji AK, Levine DI, Toffel MW (2009) How well do social ratings actually measure corporate social responsibility? J Econ Manag Strategy 18:125-169

Chih HL, Chih HH, Chen TY (2010) On the determinants of corporate social responsibility: International evidence on the financial industry. J Bus Ethics 93:115-135

Ciciretti R, Kobeissi N, Zhu Y (2014) Corporate social responsibility and financial performance: an analysis of bank community responsibility. Int J Bank Account Financ 5:342-373
Cornett MM, Erhemjamts O, Tehranian H (2016) Greed or good greeds: an examination of the relation between corporate social responsibility and the financial performance of U.S. commercial banks around the financial crisis. J Bank Financ 30:137-159

Cull R, Demirgüç-Kunt A, Lin JY (2013) Financial structure and economic development: a reassessment. World Bank Econ Rev 27:470-475

Dafermos Y, Nikolaidi M, Galanis G (2018) Climate change, financial stability and monetary policy. Ecol Econ 121:219-234

Dahlsrud A (2008) How corporate social responsibility is defined. Corp Soc Responsib Environ Manag 15:1-13

Dam L, Scholtens B (2015) Toward a theory of responsible investing: on the economic foundations of corporate social responsibility. Resour Energy Econ 41:103-121

Dietz S, Bowen A, Dixon C, Gradwell P (2016) Climate value at risk of global financial assets. Nat Clim Change 6:676-679

Dixit AK (2015) How business community institutions can help fight corruption. World Bank Econ Rev 29:S25-S47

Dorfleitner G, Halbritter G, Nguyen M (2015) Measuring the level and risk of corporate responsibility: an empirical comparison of different ESG rating approaches. J Asset Manag 16:450-466

Ferrell A, Liang H, Renneboog L (2016) Socially responsible firms. J Financ Econ 122:585-606

Friede G, Busch T, Bassen A (2015) ESG and financial performance: aggregated evidence from more than 2000 empirical studies. J Sustain Financ Invest 5:210-233

Galaz V, Crona B, Dauriach A, Scholtens B, Steffen W (2018) Finance and the Earth system-exploring the links between financial actors and non-linear changes in the climate system. Glob Environ Change 53:296-302

Garcia-Castro R, Ariño MA, Canela MA (2010) Does social performance really lead to financial performance? Accounting for endogeneity. J Bus Ethics 92:107-126

Gonenc H, Scholtens B (2019) Responsibility and performance relationship in the banking industry. Sustainability 11:3329. https://doi.org/10.3390/su11123329

Greenbaum SI, Thakor AV (2007) Contemporary financial intermediation., 2nd edn. Academic Press, Amsterdam

Heal G (2008) When principles pay. Colombia Business School, New York

Homer-Dixon T, Walker B, Biggs R, Crépin AS, Folke C, Lambin EF, Peterson GD, Rockström J, Scheffer M, Steffen W, Troell M (2015) Synchronous failure: the emerging causal architecture of global crisis. Ecol Soc 20(3):6

$\mathrm{Hu} \mathrm{V}$, Scholtens B (2014) Corporate social responsibility policies of commercial banks in developing countries. Sustain Dev 22:276-288

Hull JC (2018) Risk management and financial institutions, 5th edn. Wiley, Hoboken

Huang Y (2011) Is economic volatility detrimental to global sustainability? World Bank Econ Rev 26:128-146

Ioannou I, Serafeim G (2015) The impact of corporate social responsibility on investment recommendations: Analysts' perceptions and shifting institutional logics. Strateg Manag J 36:1053-1081

Jo H, Kim H, Park K (2015) Corporate environmental responsibility and firm performance in the financial services sector. J Bus Ethics 131:257-284

Kamal M (2013) The role of corporate social responsibility (CSR) in the Egyptian Banking Sector. Working paper. Federal Reserve Bank of St. Louis. https:// papers.ssrn.com/sol3/papers.cfm?abstract_id $=2227621$

Kemp-Benedict E (2018) Investing in a green transition. Ecol Econ 153:218-236

Keys PW, Galaz V, Dyer M, Matthews N, Folke C, Nyström M, Cornell SE (2019) Anthropocene risk. Nat Sustainability. https://doi.org/10.1038/s41893-0190327-x

Laeven L, Levine R (2009) Bank governance, regulation and risk taking. J Financ Econ 93:259-275

Laeven L, Ratnovski L, Tong H (2016) Bank size, capital, and systemic risk: some international evidence. J Bank Financ 69:S25-S34

Lins KV, Servaes H, Tamayo A (2017) Social capital, trust, and firm performance: the value of corporate social responsibility during the financial crisis. J Financ 72:1785-1823

López-Espinosa G, Rubia A, Valderrama L, Antón M (2013) Good for one, bad for all: determinants of individual versus systemic risk. J Financ Stab 9:287-299

Luo X, Bhattacharya CB (2009) The debate over doing good: corporate social performance, strategic marketing levers, and firm-idiosyncratic risk. J Mark 73:198-213

Malik MS, Nadeem M (2014) Impact of corporate social responsibility on the financial performance of banks in Pakistan. Int Lett Soc Humanist Sci 21:9-19

Mallin C, Hisham F, Kean OW (2014) Corporate social responsibility and financial performance in Islamic banks. J Econ Behav Organ 103:S21-S38

Margolis JD, Elfenbein HA, Walsh JP (2009) Does it pay to be good... and does it matter? A meta-analysis of the relationship between corporate social and financial performance. SSRN: http://ssrn.com/abstract=1866371 
Menassa E (2010) Corporate social responsibility. An exploratory study of the quality and extent of social disclosures by Lebanese commercial banks. J Appl Account Res 11:4-23

Oikonomou I, Brooks C, Pavelin S (2012) The impact of corporate social performance on financial risk and utility: a longitudinal analysis. Financ Manag 41:483-515

Orlitzky M, Schmidt FL, Rynes SL (2003) Corporate social and financial performance: a meta-analysis. Organ Stud 24:403-441

Paulik J, Majková MS, Tykva T, Cervinka M (2015) Application of the CSR measuring model in commercial banking in relation to their financial performance. Econ Sociol 8:64-81

Platonova E, Asutay M, Dixon R, Mohammad S (2016) The impact of corporate social responsibility disclosure on financial performance: evidence from the GCC Islamic banking sector. J Business Ethics. https://doi.org/10.1007/ s10551-016-3229-0

Saxena M, Kohli AS (2012) Impact of corporate social responsibility on corporate sustainability: a study of the Indian banking industry. J Corp Gov 11(4):1-16

Scholtens B (2007) Financial and social performance of socially responsible investments in the Netherlands. Corp Gov 15:1090-1105

Scholtens B (2008) A note on the interaction between corporate social responsibility and financial performance. Ecol Econ 68:46-55

Schröder M (2014) Financial effects of corporate social responsibility: a literature review. J Sustain Financ Invest 4:337-350

Scholtens B (2017) Why finance should care about ecology. Trends Ecol Evol 32:500-505

Semenova N, Hassel LG (2015) On the validity of environmental performance metrics. J Bus Ethics 132:249-258

Shen $\mathrm{CH}, \mathrm{Wu}$ MW, Chen TH, Fang $\mathrm{H}$ (2016) To engage or not to engage in corporate social responsibility: Empirical evidence from global banking sector. Econ Model 55:207-225

Simpson G, Kohers T (2002) The link between corporate social and financial performance: evidence from the banking industry. J Bus Ethics 35:97-109

Soana MG (2011) The relationship between corporate social performance and corporate financial performance in the banking sector. J Bus Ethics 104:133-148

Sun W, Cui K (2014) Linking corporate social responsibility to firm default risk. Eur Manag J 32:275-287

Tobin J (1987) Financial intermediaries. In:Eatwell J, Milgate M, Newman P (eds) The New Palgrave, Money. MacMillan, London and Basingstoke, pp 157-174
Uddin S, Islam MZ, Hasan I (2012) Corporate social responsibility and financial performance linkage-Evidence from the banking sector of Bangladesh. J Organ Manag 1:14-21

Waddock S, Graves S (1997) Finding the link between stakeholder relations and quality of management. J Invest 6(4):20-24

Wu MW, Shen $\mathrm{CH}$ (2013) Corporate social responsibility in the banking industry: motives and financial performance. J Bank Financ 37:3529-3547

Wu MW, Shen CH, Chen TH (2017) Application of multi-level matching between financial performance and corporate social responsibility in the banking industry. Rev Quant Financ Account 49:29-63

\section{Additional information}

The online version of this article (https://doi.org/10.1057/s41599-019-0315-9) contains supplementary material, which is available to authorized users.

Competing interests: The authors declare no competing interests.

Reprints and permission information is available online at http://www.nature.com/ reprints

Publisher's note: Springer Nature remains neutral with regard to jurisdictional claims in published maps and institutional affiliations.

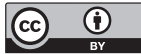

Open Access This article is licensed under a Creative Commons Attribution 4.0 International License, which permits use, sharing, adaptation, distribution and reproduction in any medium or format, as long as you give appropriate credit to the original author(s) and the source, provide a link to the Creative Commons license, and indicate if changes were made. The images or other third party material in this article are included in the article's Creative Commons license, unless indicated otherwise in a credit line to the material. If material is not included in the article's Creative Commons license and your intended use is not permitted by statutory regulation or exceeds the permitted use, you will need to obtain permission directly from the copyright holder. To view a copy of this license, visit http://creativecommons.org/ licenses/by/4.0/

(C) The Author(s) 2019 